\section{Kan psykose forebygges?}

\author{
Studier antyder at kognitiv atferds- \\ terapi kan forhindre eller utsette \\ psykose hos høyrisikopersoner.
}

Perioden før manifest psykose inntrer karakteriseres ved en rekke uspesifikke psykologiske symptomer og endret atferd. For schizofreni varer denne prodromalperioden i ett til tre år. Britiske forskere har i en metaanalyse undersøkt om psykologiske, farmakologiske eller ernæringsmessige intervensjoner kan forhindre eller utsette psykose hos høyrisikopersoner (1).

Analysen omfattet 11 studier med totalt 1246 deltakere. Forskerne fant at kognitiv atferdsterapi førte til en reduksjon i overgang til psykose etter 12 måneder (risikoratio $0,54(95 \% \mathrm{KI} 0,34-0,86)$. Effekt av henholdsvis omega-3-fettsyrer og integrert psykoterapi hadde muligens også en effekt, men kvaliteten på studiene var dårlige.

- Flere metaanalyser har nå vist at det er mulig å hindre overgang til psykose ved såkalt ultrahøyrisikotilstander (UHR). Resultatene er noe springende vedrørende de psykologiske intervensjonene, men individbasert stressreduksjon ser ut til å være et fellestrekk ved de virksomme tilnærmingene, sier sjeflege Jan Olav Johannessen ved Psykiatrisk divisjon, Stavanger universitetssjukehus.

- Forskningen om omega-3 er lovende, og flere steder utføres det nå randomiserte, kontrollerte studier for å se om man kan replikere den ene studien som så langt foreligger, sier Johannessen.

\section{Trine B. Haugen}

trine.b.haugen@hioa.no

Tidsskriftet

\section{Litteratur}

1. Stafford MR, Jackson H, Mayo-Wilson E et al. Early interventions to prevent psychosis: systematic review and meta-analysis. BMJ 2013; 346: f185.

\title{
Koleraepidemien på Haiti
}

\author{
Etter jordskjelvet i 2010 brøt det ut en større koleraepidemi på Haiti. \\ Utbruddet førte til at over halvparten av de rapporterte koleratilfellene \\ i verden i 2010 og 2011 var fra Haiti.
}

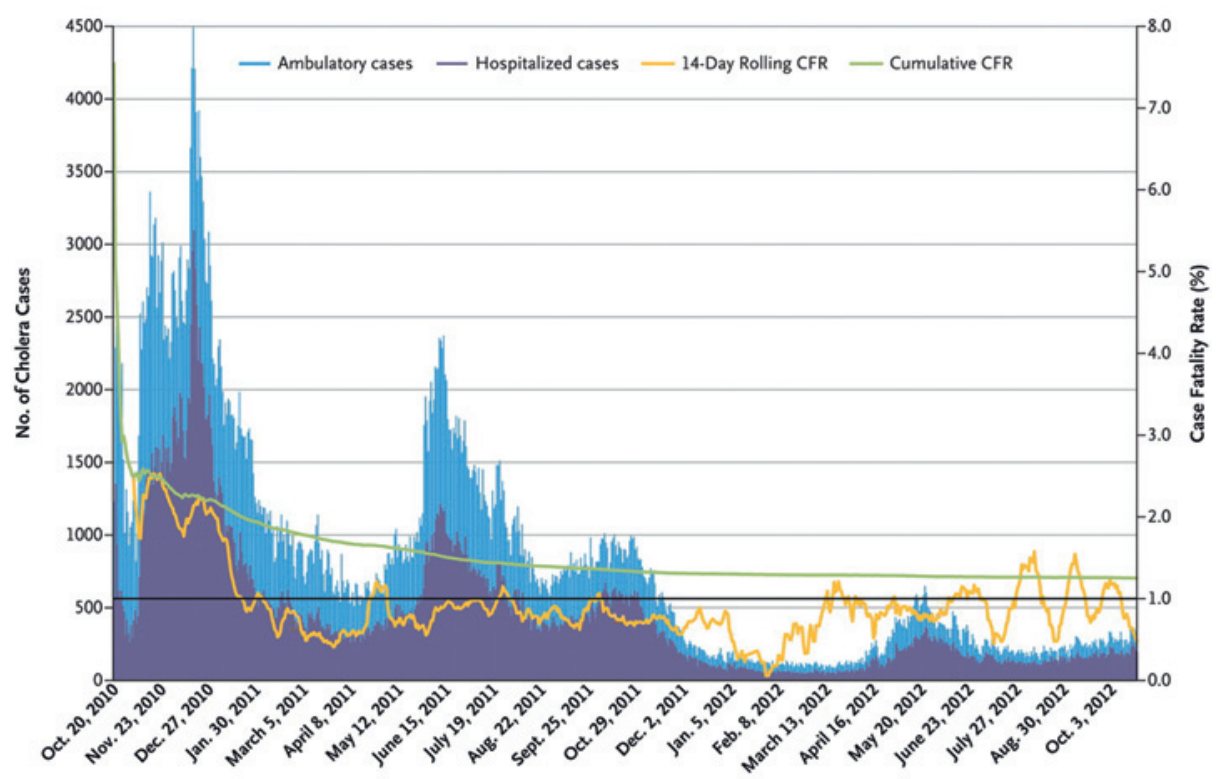

Nye tilfeller av kolera og sykehusinnleggelser på Haiti i en toårsperiode (1). Gjengitt med tillatelse

Haiti ble rammet av et stort jordskjelv i januar 2010, og skjelvet medførte store skader på en allerede mangelfull infrastruktur. En stor del av befolkningen manglet tilgang på rent vann og gode sanitærforhold, og $\mathrm{i}$ oktober 2010 ble det oppdaget flere tilfeller av diarésykdommen kolera (1). Det ble igangsatt et overvåkingsprogram (National Cholera Surveillance System, NCSS) som fulgte utviklingen av utbruddet $\mathrm{i}$ alle Haitis ti regioner. WHOs definisjon for å diagnostisere kolera ble brukt, men modifisert til også å inkludere barn under fem år.

Fra oppstart i oktober 2010 til oktober to år senere ble det rapportert over 600000 tilfeller av kolera, og 7436 dødsfall som følge av infeksjonen. $13 \%$ av sykdomstilfellene og $8 \%$ av dødsfallene gjaldt barn under fem år. I 2010 og 2011 utgjorde epidemien henholdsvis $57 \%$ og $58 \%$ av koleratilfeller rapportert til WHO, og tilsvarende $53 \%$ og $37 \%$ av alle kolerarelaterte dødsfall.

I en ledsagende kommentar til artikkelen blir det påpekt at kolera fortsatt er et stort helseproblem i utviklingsland, og antallet innrapporterte tilfeller underestimerer omfanget som er anslått til 3-5 millioner tilfeller årlig (2). Stadig flere mennesker i utviklingsland får tilgang på rent drikkevann, men fortsatt lever over en milliard mennesker helt uten sanitæranlegg. Selv om antibiotika og vaksiner er tilgjengelig mange steder, er tilgang på rent vann og gode sanitærforhold av avgjørende betydning hvis man skal klare å utrydde kolera (2).

\section{Merete Kile Holtermann}

merete.holtermann@legeforeningen.no Tidsskriftet

\section{Litteratur}

1. Barzilay EJ, Schaad N, Magloire R et al. Cholera surveillance during the Haiti epidemic-the first 2 years. N Engl J Med 2013; 368: 599-609.

2. Waldman RJ, Mintz ED, Papowitz HE. The cure for cholera - improving access to safe water and sanitation. N Engl J Med 2013; 368: 592-4. 